\title{
The ecology of freshwater bivalves in the Lake Sapanca basin, Turkey
}

\author{
${\text { Ertan } \text { ERCAN }^{1}{ }^{\star} \text {, Özcan GAYGUSUZ }}^{2}$, Ali Serhan TARKAN ${ }^{1}$, Martin REICHARD $^{3}$, Carl SMITH $^{4}$ \\ ${ }^{1}$ Faculty of Fisheries, Muğla Sıtkı Koçman University, Kotekli, Muğla, Turkey \\ ${ }^{2}$ Faculty of Fisheries, İstanbul University, Laleli, İstanbul, Turkey \\ ${ }^{3}$ Institute of Vertebrate Biology, Academy of Sciences of the Czech Republic, Květná 8, 60365 Brno, Czech Republic \\ ${ }^{4}$ School of Biology, University of St. Andrews, St. Andrews, Fife, UK
}

\begin{abstract}
Despite the ecological importance and globally threatened status of freshwater bivalves, the freshwater mussel fauna of Turkey has hitherto received little attention. The aim of this study was to describe the ecology of freshwater mussels of the Lake Sapanca basin (northwest Turkey) to provide baseline data against which to measure future trends. Five native mussel species belonging to 3 genera were encountered in surveys: Anodonta cygnea, A. anatina, Unio pictorum, U. crassus, and Dreissena polymorpha. In addition, an invasive species from Asia, A. woodiana, was recorded in the region for the first time. A. cygnea and U. pictorum were the most abundant species in the lake, while $U$. crassus was most abundant in the associated stream. Age and growth parameters were estimated for $U$. pictorum and $U$. crassus, and indicated that the latter species had a younger median age and faster growth rate than the former, possibly a function of exclusively occupying a nutrient-enriched stream. The bioecological features of the bivalve fauna of the Lake Sapanca basin, as well as the implications of the introduction of $A$. woodiana, are discussed.
\end{abstract}

Key words: Turkey, water quality, invasive species, age, growth

\section{Introduction}

Freshwater bivalves are a key component of the ecology of aquatic ecosystems. As sedentary suspension feeders, they have a direct impact on suspended material in the water column and potentially exert bottom-up control on phytoplankton blooms (Vaughn et al., 2008; Allen et al., 2011). Large bivalve populations can influence the calcium budget of the water bodies in which they occur (Green, 1980), and they provide an integral resource link between freshwater pelagic and benthic habitats (Howard and Cuffe, 2006; Strayer, 2008). The amount and rate of particulate matter removed from the water column by bivalves can be considerable, and freshwater mussels can function in the rehabilitation of organically polluted waters, particularly those associated with aquaculture (Ercan, 2009). In addition, freshwater mussels are preyed upon by a range of terrestrial and aquatic organisms (Öktener, 2004; Vaughn, 2010). They serve as the intermediate hosts for several parasitic species, and some species are themselves parasitic as larvae (Dillon, 2000). Globally, freshwater bivalves are threatened, primarily through habitat deterioration, and in some cases through direct exploitation (Lydeard et al., 2004).

Despite their key ecological role and threatened status, mussel faunas in many regions are poorly studied and there

* Correspondence: ertanercan@mu.edu.tr are few baseline data against which to measure ongoing population declines or recovery. In Turkey, freshwater bivalve communities have received little attention, though a limited number of studies have addressed their biology in Turkish freshwaters (Akyurt and Erdoğan, 1993; Kara, 2004; Yalçın, 2006; Koşal Şahin and Yıldırım, 2007; Ercan, 2009; Yllmaz, 2011). Additionally, the taxonomic status of many bivalves has yet to receive revision in light of modern molecular biology techniques. In this study, we describe the freshwater bivalve community of the Lake Sapanca basin in northwestern Turkey. Lake Sapanca is an important water body in northwestern Turkey, both from an ecological and economic perspective. An initial survey of the mollusk fauna of Lake Sapanca was performed by Koşal Şahin and Yıldırım (2007) using grab and dredge sampling. Using these techniques, they identified 4 species of bivalves, of which 2 were unionids (Anodonta anatina and Unio pictorum). Our aim was to perform more comprehensive dive surveys of the bivalve fauna, as well as estimating age and growth parameters on the most common mussel species in the lake. We also assessed the bioecological features of the native mussel fauna and considered the potential implications of an invasive bivalve species in the region. 


\section{Materials and methods}

Lake Sapanca is located in the Marmara region of northwestern Turkey $\left(40^{\circ} 41^{\prime}\right.$ to $40^{\circ} 30^{\prime} \mathrm{N}, 30^{\circ} 09^{\prime}$ to $30^{\circ} 20^{\prime} \mathrm{E}$ ) and is one of the most important lakes in the region in terms of its fisheries and as a source of drinking water (Figure 1). Its surface area is $46.8 \mathrm{~km}^{2}$ with a maximum depth of $55 \mathrm{~m}$. It is $30 \mathrm{~m}$ above sea level, with 13 rivers flowing into the lake (the rivers Karaçay, Yanık, Kurtköy, Mahmudiye, İstanbul, Maşukiye, Keçi, Sarp, Balıkhane, Eşme, Liman, Maden, and Arifiye). The lake has one outflowing river (Çark). The lake is used as a source of drinking water for the city and district of Sakarya and as a recreational amenity. Although Lake Sapanca water shows evidence of enrichment with nitrates and phosphates from trout farms, of which there are more than 30 in the vicinity of the lake, it has an oligotrophic character (Albay et al., 2003). Sampling stations around the lake and in associated rivers were chosen to be representative of the major habitat types in the lake. There are 3 sampling stations in total: 1 in the Maşukiye River, 1 at the southern shore (at the mouth of the Yanik River), and 1 at the northern shore of Lake Sapanca (Figure 1). The Maşukiye River site was the most impacted, since sampling was conducted downstream of its confluence with the Ballkhane River, which has high quantities of suspended organic and inorganic material derived from anthropogenic activities. Sampling sites were concentrated on the western shore of the lake, since mussels were most abundant there (Koşal Şahin and Yildirım, 2007).

Bivalve surveys were conducted between 2007 and 2009 by hand collection to a maximum water depth of $3 \mathrm{~m}$. Hand collection was used in combination with a bathyscope to spot mussel siphons at the sediment surface. All bivalves were measured (width, height, and length) using digital calipers to the nearest $0.1 \mathrm{~mm}$ and their wet weight determined on an electronic balance to the nearest 0.001 $\mathrm{g}$ (Bilgin, 1980). Identification of mussels was performed in accordance with Killeen et al. (2004). The number of $D$. polymorpha individuals attached to the shells of Anodonta species and U. pictorum was counted. Density of Unio and Anodonta spp. at the sampling sites was calculated as the number of individuals per $\mathrm{m}^{2}$, which was determined by transects. Mussel collection was maintained for $30 \mathrm{~min}$ with skin diving in each sampling occasion.

Age was determined by thin sectioning of shells (Singer and Gangloff, 2011), confirmed by lengthfrequency analysis (e.g., Negus, 1966). Age determination was possible only for Unio species; the shells of Anodonta spp. were too thin to section and score reliably (Neves and Moyer, 1988). Fresh dead shell material for sectioning was collected at sample site 1 (Figure 1).

Length-weight relationships of mussels were estimated using the function: $\mathrm{W}=a \mathrm{~L}^{b}$, where $\mathrm{W}$ is the total (wet) weight (expressed in grams), $\mathrm{L}$ is the total shell length

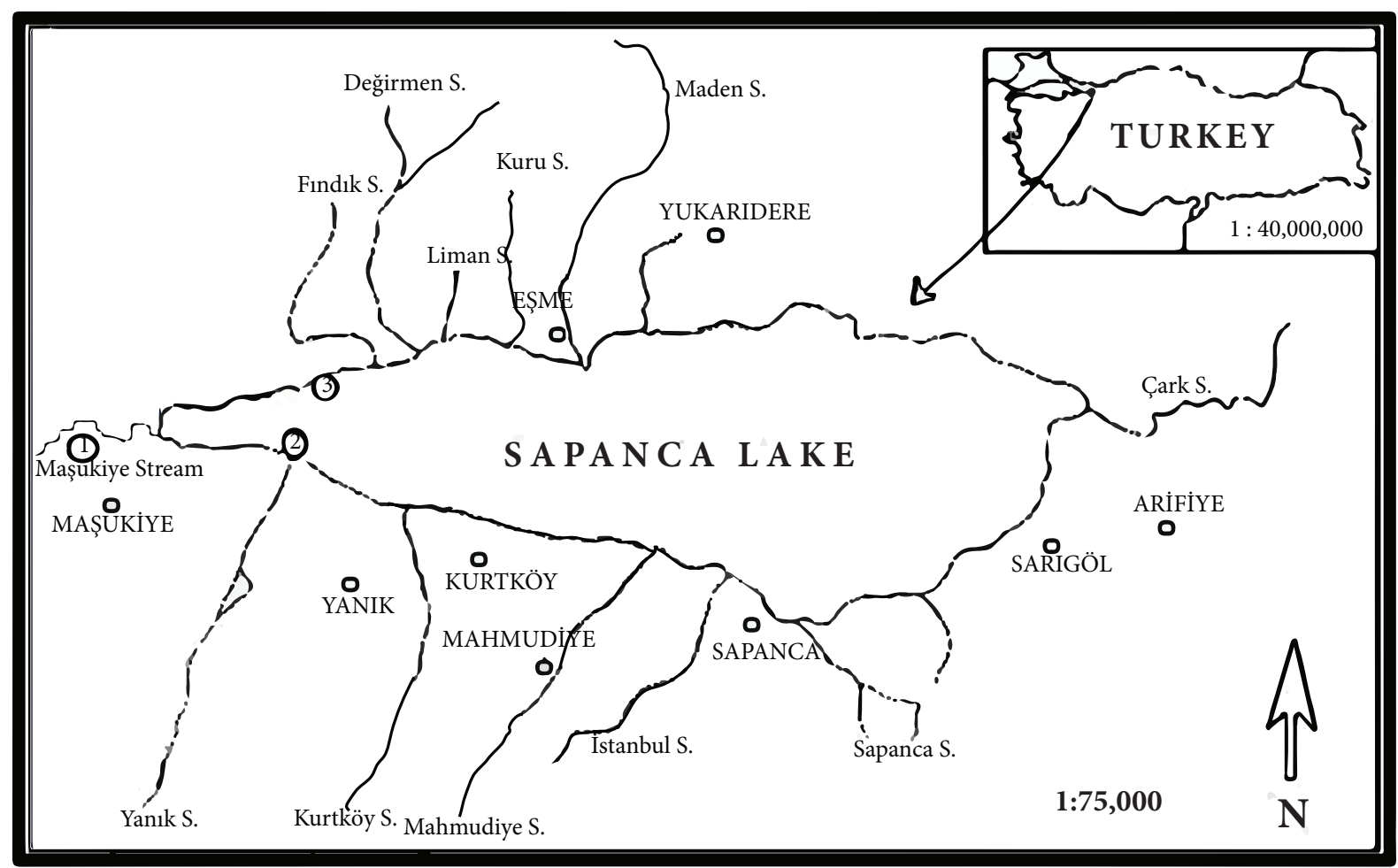

Figure 1. Sampling sites in the Lake Sapanca basin. 
(expressed in millimeters), and $a$ and $b$ are the parameters of the equation. Regressions on log-transformed data were analyzed using analyses of covariance (ANCOVA) to examine differences in slopes between species (Zar, 1999). Total shell radius (R) and the radius of annual rings were measured as the smallest distance between the shell center and the distal edge. Lengths at previous ages were back-calculated using the Fraser-Lee equation (Francis, 1990): $L_{t}=c+\left(L_{c}-c\right)\left(S_{t} / R\right)$, where $L_{t}$ is $L$ when growth mark $t$ was formed, $L_{c}$ is $L$ at the time of capture, $S_{t}$ is the distance from shell center to the growth mark $t, R$ is shell radius, and $\mathrm{c}$ is the intercept on the length axis of the linear regression between $\mathrm{L}$ and shell radius. The von Bertalanffy growth equation was fitted to lengths at age. The form of the growth curve is $\mathrm{L}_{\mathrm{t}}=\mathrm{L}_{\infty}\left\{1-\mathrm{e}^{-\mathrm{k}(\mathrm{t}-\mathrm{to})}\right\}$ (Ricker, 1975), where $L_{t}$ is the total length of mussel at time $t, L_{\infty}$ is the asymptotic total length, $\mathrm{k}$ is the growth coefficient, and $\mathrm{t}_{\mathrm{o}}$ is the hypothetical time at which mussel total length is zero.

Since there was no fishery for mussels in the Lake Sapanca basin, total mussel mortality comprised only natural mortality, which was estimated using the empirical formula of Pauly (1980), $\log (\mathrm{M})=-0.0066-0.279 \log$ $\left(\mathrm{L}_{\infty}\right)+0.6543 \log (\mathrm{k})+0.463 \log (\mathrm{T})$, where $\mathrm{L}_{\infty}$ and $\mathrm{k}$ are the parameters derived from the von Bertalanffy equation and $\mathrm{T}$ is the average water temperature in ${ }^{\circ} \mathrm{C}$ throughout the study period $\left(15.2^{\circ} \mathrm{C}\right.$ in this case).

Water samples were collected at each of the sampling sites throughout the sampling period for nutrient analyses and stored at $-20{ }^{\circ} \mathrm{C}$ in a freezer and in darkness until analysis. Standard Methods for the Examination of Water and Wastewater (APHA et al., 1985) were used for all analyses. Physicochemical water parameters including temperature, dissolved oxygen, conductivity, and $\mathrm{pH}$ were measured in the field using a multi-parameter probe (WTW 310i). For chlorophyll- $a$ analysis, water samples was first filtered and then extracted through ethanol. After centrifugation, absorbance was measured before and after acidification in a spectrophotometer (Ryther and Yentsch, 1957).

\section{Results}

\subsection{Environmental variables}

Seasonally collected environmental variables showed that the Maşukiye River had a higher nutrient content than the other sample sites (Table 1). U. crassus occurred exclusively in the Maşukiye River (see below), and was positively correlated with chemical parameters indicating enriched waters $\left(\mathrm{NO}_{2}, \mathrm{NO}_{3}, \mathrm{PO}_{4}, \mathrm{TP}\right)$ and low water temperature (Table $1, r>0.82, \mathrm{P}<0.01$ ). The abundance of the other bivalve species was not correlated with the chemical and physical variables measured in the study (Table 1).

\subsection{Bivalve fauna}

Six species of bivalve belonging to 3 genera were collected in surveys: A. cygnea, A. anatina, A. woodiana, U. pictorum, $U$. crassus, and D. polymorpha. The Chinese mussel $A$. woodiana, which is an alien species, was recorded here for the first time in the Turkish mussel fauna, while U. crassus and $A$. anatina were new records for the Lake Sapanca basin. U. crassus and A. woodiana were collected only from the Maşukiye River (sample site 1), which discharges into Lake Sapanca, whereas the other species were found at the mouth of the Yanık River (sample site 2) and in the western part of the lake (sample site 3) (Figure 1).

$U$. crassus showed the highest density in the Maşukiye River (sampling site 1), while A. cygnea showed the highest density in the lake proper. U. pictorum showed the highest density at site 2 , while A. anatina showed consistently low densities overall, though it was encountered at all sampling sites. U. crassus and A. woodiana only occurred in the Maşukiye River (Table 2). D. polymorpha occurred

Table 1. Mean and standard deviations $( \pm)$ of physico-chemical parameters of sampling stations in the Lake Sapanca basin.

\begin{tabular}{llll}
\hline Physico-chemical parameters & Site 1 & Site 2 & Site 3 \\
\hline Total phosphorous $\left(\mu \mathrm{g} \mathrm{L}^{-1}\right)$ & $80.8( \pm 51.0)$ & $10.1( \pm 1.7)$ & $25.0( \pm 5.2)$ \\
Phosphate $\left(\mu \mathrm{g} \mathrm{L}^{-1}\right)$ & $38.8( \pm 49.9)$ & $9.9( \pm 5.1)$ & $13.2( \pm 3.1)$ \\
Nitrite $\left(\mu \mathrm{g} \mathrm{L}^{-1}\right)$ & $13.4( \pm 8.1)$ & $1.9( \pm 1.6)$ & $1.3( \pm 0.9)$ \\
Nitrate $\left(\mu \mathrm{g} \mathrm{L}^{-1}\right)$ & $530.7( \pm 124.4)$ & $157.3( \pm 61.0)$ & $150.0( \pm 55.0)$ \\
Sulphate $\left(\mathrm{mg} \mathrm{L}^{-1}\right)$ & $23.3( \pm 5.5)$ & $55.9( \pm 22.5)$ & $46.3( \pm 12.1)$ \\
Silicon dioxide $\left(\mathrm{mg} \mathrm{L}^{-1}\right)$ & $3.8( \pm 0.9)$ & $3.6( \pm 0.5)$ & $2.4( \pm 0.4)$ \\
Chlorophyll $a\left(\mathrm{mg} \mathrm{L}^{-1}\right)$ & $1.2( \pm 0.7)$ & $0.9( \pm 4.9)$ & $2.6( \pm 5.1)$ \\
Dissolved oxygen $(\mathrm{ppt})$ & $12.3( \pm 2.4)$ & $7.7( \pm 0.9)$ & $10.1( \pm 2.2)$ \\
pH & $8.0( \pm 0.1)$ & $8.0( \pm 0.1)$ & $8.2( \pm 0.2)$ \\
Temperature $\left({ }^{\circ} \mathrm{C}\right)$ & $13.2( \pm 2.2)$ & $15.5( \pm 2.6)$ & $16.3( \pm 4.6)$ \\
\hline
\end{tabular}


Table 2. Density (individuals per $\mathrm{m}^{2}$ ) of Unio and Anodonta spp. at 3 sampling sites in the Lake Sapanca basin.

\begin{tabular}{llll}
\hline Species & Site 1 & Site 2 & Site 3 \\
\hline A. cygnea & 30 & 36 & 73 \\
A. anatina & 13 & 15 & 8 \\
A. woodiana & 1 & - & - \\
U. pictorum & 15 & 48 & 17 \\
U. crassus & 45 & - & - \\
\hline
\end{tabular}

at sampling sites 2 and 3 , and was primarily found attached to the other bivalve species.

3.3. Age, growth, length-weight relationships, and mortality estimates

Age estimation of $U$. pictorum and $U$. crassus indicated a maximum age of collected specimens to be 13 and 7 years old, respectively. Estimates of Brody's growth constant (k) were 0.26 year $^{-1}$ for $U$. crassus and 0.19 year $^{-1}$ for $U$. pictorum, indicating that $U$. crassus had a faster growth rate than $U$. pictorum (Figure 2). Theoretical maximum lengths $\left(L_{\infty}, \mathrm{cm}\right)$ were $96.2 \mathrm{~mm}$ and $89.6 \mathrm{~mm}$ for $U$. pictorum and $U$. crassus, respectively. $U$. crassus had a higher estimated natural instantaneous mortality rate of 0.41 year $^{-1}$, compared with 0.33 year $^{-1}$ for $U$. pictorum. The slope of the length-weight relationships of the 4 unionid species collected, excluding $A$. woodiana for which there were insufficient data to estimate the parameter, varied between 2.47 for $U$. crassus and 2.97 for U. pictorum (Table 3). There were significant differences in the slopes of the length-weight relationships among the species (ANCOVA, $\mathrm{P}<0.01)$. Size ranges were similar for Unio species and $A$. anatina; however, A. cygnea shell length was almost twice as long as for the other species examined (Figure 3). Plots of the length-frequency distribution showed that medium sizes were dominant with the exception of A. anatina, which had a relatively homogeneous length distribution (Figure 3).

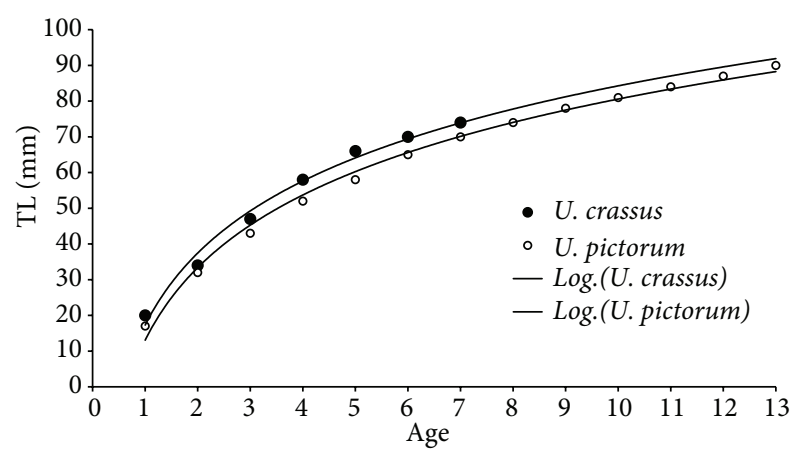

Figure 2. Growth curves of Unio crassus and U. pictorum from the Lake Sapanca basin.

\section{Discussion}

The aim of this study was to describe the ecology of freshwater mussels of the Lake Sapanca basin (northwestern Turkey) to provide baseline data against which to measure future trends. Six species of bivalve were collected, 1 of which was a nonnative species. A previous survey on the mollusk fauna of Lake Sapanca reported only 2 unionid species, namely U. pictorum and A. cygnea (Koşal Şahin and Yıldırım, 2007). These species were also identified in the present study. In addition, 2 further native species (U. crassus and A. anatina) and 1 nonnative species (A. woodiana) were recorded, which were not recorded in the survey by Koşal Şahin and Yıldırım (2007). Given the relatively high abundance of $U$. crassus and A. anatina in the lake, the failure to identify them in the previous survey may have been through misidentification of samples, or as a consequence of selectivity in the sampling methods used, which were with an Ekman grab and hand dredge. Koşal Şahin and Yıldırım (2007) also sampled only from the main body of the lake, not from streams flowing into the lake, which could be another reason why they did not encounter $U$. crassus; this species was encountered exclusively in one stream (Table 2). It is notable that Koşal Şahin and Yildırım (2007) encountered one bivalve species, Sphaerium lacustre, which was not recorded in the present study. Our failure to collect $S$. lacustre, which is a

Table 3. Mean values ( \pm standard deviation) of length, width, height, weight, and parameters of the length-weight relationship of freshwater bivalve species in the Lake Sapanca basin.

\begin{tabular}{lllllll}
\hline Species & Length $(\mathrm{mm})$ & Width $(\mathrm{mm})$ & Height $(\mathrm{mm})$ & Weight $(\mathrm{g})$ & $\mathrm{a}$ & $\mathrm{b}$ \\
\hline U. pictorum & $69.57( \pm 7.12)$ & $32.54( \pm 3.33)$ & $22.39( \pm 2.71)$ & $31.84( \pm 9.99)$ & 0.0001 & 2.97 \\
U. crassus & $61.44( \pm 4.81)$ & $33.01( \pm 1.91)$ & $23.10( \pm 1.75)$ & $31.05( \pm 6.33)$ & 0.0012 & 2.47 \\
A. anatina & $68.18( \pm 8.05)$ & $40.25( \pm 4.46)$ & $19.15( \pm 2.60)$ & $25.34( \pm 8.62)$ & 0.0002 & 2.78 \\
A. cygnea & $106.83( \pm 1.31)$ & $51.30( \pm 0.60)$ & $33.53( \pm 2.59)$ & $87.78( \pm 30.20)$ & 0.0001 & 2.87 \\
D. polymorpha & $15.34( \pm 5.24)$ & $8.31( \pm 2.98)$ & $7.72( \pm 3.20)$ & $0.84( \pm 1.10)$ & 0.0004 & 3.21 \\
A. woodiana & 71.20 & 35.07 & 45.03 & 64.30 & - \\
\hline
\end{tabular}



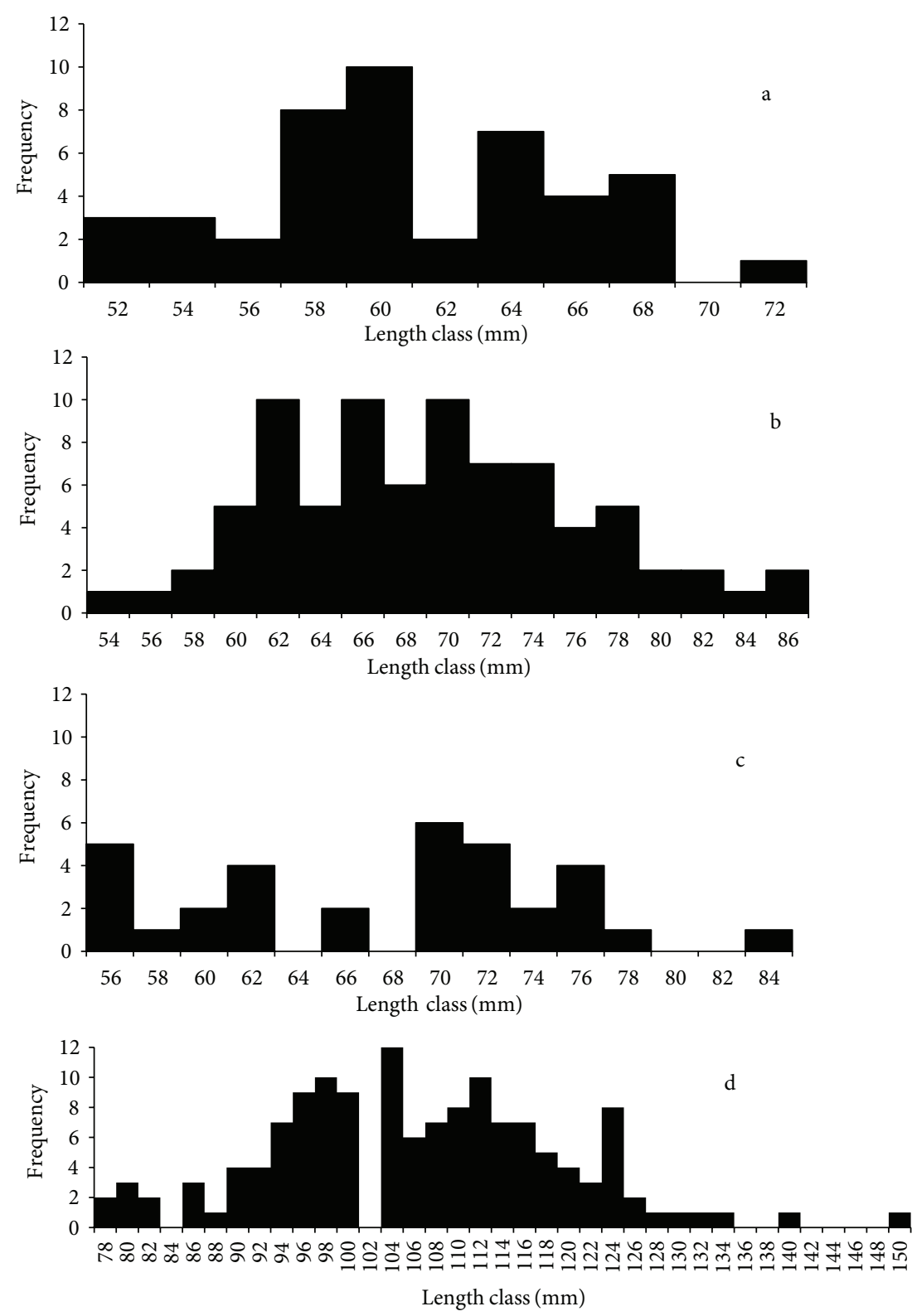

Figure 3. Length-frequency distribution of (a) Unio crassus, (b) Unio pictorum, (c) Anodonta anatina, (d) Anodonta cygnea in the Lake Sapanca basin.

small species (typically $<10 \mathrm{~mm}$ maximum length), may also have been a result of the hand-searching sampling method used, which is inefficient for small specimens.

The relative abundance of native unionid species from the Lake Sapanca basin suggests that of the 2 Unio species $U$. pictorum was the most abundant species in the lake proper, while $U$. crassus was dominant in the Maşukiye River, which discharges into the lake. U. crassus has previously been reported as the dominant unionid species in lotic waters elsewhere (Kiss, 1994; İlhan et al., 2004). Overall, A. cygnea was the most abundant unionid throughout the entire lake basin, while A. anatina occurred at lower densities, but was encountered at all 3 sampling sites.

Despite occupying a distinct ecological niche in comparison with the unionid species, $D$. polymorpha was abundant in the lake. D. polymorpha is widely distributed throughout the Black Sea region (Son, 2007), and tends to be abundant where it is found (Gaygusuz et al., 2007; Vrtílek and Reichard, 2012). It has well-described negative impacts, such as obstructing pipelines (DSI, 2005) and fouling unionid mussels (Lewandowski, 1976; Schloesser et al., 1996). Although native to Turkey (e.g., May et al., 2006; Son, 2007), D. polymorpha also has negative effects in the Lake Sapanca basin. Most D. polymorpha collected 
during the present study were only found attached to the shells of unionids. D. polymorpha is known to compete with unionids for food particles (Baker and Hornbach, 2000) and to deform their shells by fouling (Schloesser et al., 1996). There has been a marked increase in the abundance of $D$. polymorpha between the time at which Koşal Şahin and Yıldırım (2007) conducted their sampling in 2000 and 2001 and the present study in 2007 and 2009. Further monitoring of the $D$. polymorpha population of the Lake Sapanca basin is needed to chart the increase of this species, and to intervene to protect the unionid populations if necessary.

$U$. crassus is considered an endangered species in Europe (Cuttelod et al., 2011), and is typically associated with clear water conditions (Zettler and Jueg, 2007). Indeed, occurrence of $U$. crassus was reported to be characterized by high chemical oxygen demand and high dissolved oxygen content (Bauer, 1988; Douda, 2010). This was supported by the fact that $U$. crassus is not present in lentic waters, where the oxygen content is more limited. The present study showed a strong association of this species with the nutrient-enriched Maşukiye River (Table 1 ). The distribution of $U$. crassus appears to be associated with lotic waters rather than with water with high nutrient loads (Kiss, 1994; İlhan et al., 2004), though our findings indicate that this species is at least tolerant of relatively low water quality. Köhler (2006) linked low survival of juvenile $U$. crassus to nitrate concentrations below $2 \mathrm{mg} \mathrm{L}^{-1}$, and nitrate concentrations between 2 and $10 \mathrm{mg} \mathrm{L}^{-1}$ have been associated with limited or failed recruitment (Zettler and Jueg, 2007). This is in agreement with the situation in the Lake Sapanca basin, as U. crassus had a healthy population at nitrate concentrations between 0.4 and $0.6 \mathrm{mg} \mathrm{L}^{-1}$ in the Maşukiye River (Table 1). Thus, while high nitrate concentrations may be partially responsible for declines in $U$. crassus, it would appear not to be the only factor limiting this species.

The growth and size parameters of the bivalve species collected in the present study differ somewhat from those of other studies from this region (Akyurt and Erdoğan, 1993; Kara, 2004; Yalçın, 2006) and elsewhere in Europe (Negus, 1966) (Table 4). Both Unio species exhibited different growth rates, as might be anticipated from the different systems and habitats they occupy (Table 4 ). $U$. pictorum was found primarily in the lake, though it did occur in low densities in the river at site 1 . U. crassus appeared to be more specialized in its habitat requirements and was exclusively encountered in the river habitat. The older age profile of $U$. pictorum relative to $U$. crassus fits the predicted negative relationship between growth coefficient $(k)$ and lifespan (Metcalfe and Monaghan, 2003). A similar pattern was recorded for the Tisza River in Hungary, indicating that $U$. crassus has a faster growth rate but a shorter lifespan (Kiss, 1994). The slopes of the lengthweight relationships indicated that $U$. pictorum had a greater weight gain per unit length in comparison with $U$. crassus. There are some comparable estimates of $b$ for $U$. pictorum (Kiss, 1994; Yalçın, 2006) and U. crassus (Kiss, 1994) that report higher estimates than ours for these species, with the exception of Kiss (1994), who estimated a lower value of $b$ for $U$. pictorum (Table 4). A previous study from England (Negus, 1966) on the age and growth of $U$. pictorum from the River Thames yielded a similar pattern of growth and lifespan. However, comparable works from

Table 4. Comparison of length at age ( $\mathrm{mm})$, maximum age and length, and slope (b) of the length-weight relationship for U. pictorum, U. crassus, and A. cyngnea.

\begin{tabular}{|c|c|c|c|c|c|c|c|c|c|c|c|c|c|c|c|c|c|}
\hline & \multicolumn{17}{|c|}{ Length at age (mm) } \\
\hline & 1 & 2 & 3 & 4 & 5 & 6 & 7 & 8 & 9 & 10 & 11 & 12 & 13 & $\begin{array}{l}\text { Lifespan } \\
\text { (years) }\end{array}$ & $\begin{array}{l}\text { Max. length } \\
(\mathrm{mm})\end{array}$ & $\mathrm{b}$ & Reference \\
\hline U. pictorum & 17 & 32 & 43 & 52 & 58 & 65 & 70 & 74 & 78 & 81 & 84 & 87 & 90 & 13 & 90 & 2.97 & Present study \\
\hline U. pictorum & - & 38 & 53 & 64 & 72 & 72 & 78 & 80 & 81 & - & - & - & - & 9 & 81 & - & Kara (2004) \\
\hline U. pictorum & - & - & - & - & - & - & - & - & - & - & - & - & - & - & - & 3.16 & Yalçın (2006) \\
\hline U. pictorum & - & - & - & - & - & - & - & - & - & - & - & - & - & 13 & 75 & - & Negus (1966) \\
\hline U. pictorum & - & - & - & - & - & - & - & - & - & - & - & - & - & - & - & 2.66 & Kiss (1994) \\
\hline U. crassus & 20 & 34 & 47 & 58 & 66 & 70 & 74 & - & - & - & - & - & - & 7 & 74 & 2.47 & Present study \\
\hline U. crassus & 19 & 29 & 42 & 52 & 53 & 58 & 61 & - & - & - & - & - & - & 7 & 61 & - & $\begin{array}{l}\text { Akyurt and Erdoğan } \\
\text { (1993) }\end{array}$ \\
\hline U. crassus & - & - & - & - & - & - & - & - & - & - & - & - & - & - & - & 2.82 & Kiss (1994) \\
\hline A. cygnea & - & - & - & - & - & - & - & - & - & - & - & - & - & - & 150 & 2.87 & Present study \\
\hline A. cygnea & - & - & - & - & - & - & - & - & - & - & - & - & - & - & 145 & 2.89 & Başçınar (2003) \\
\hline
\end{tabular}


Turkey (Akyurt and Erdoğan, 1993; Kara, 2004) recorded contrasting growth rates (both slower and faster) with shorter lifespans (Table 4). The fact that these studies made estimates of age based on counting external growth bands on the shells, which has been considered an unreliable method for ageing due to underestimation of older specimens (Neves and Moyer, 1988), may explain some of these growth variations among studies. Notwithstanding the limitations of this method, it would appear that the growth and lifespan of Unio species are variable in Turkey, perhaps related to variation in temperature and water quality. Although Anodonta species were not aged in the present study because of their thin shells, our estimates of $b$ for A. cygnea corresponded closely with those of Lake Çıldır in eastern Turkey (Başçınar 2003), though there were differences in maximum shell length (Table 4).

The occurrence of $A$. woodiana in the Lake Sapanca basin represents the first record for Turkish waters. This species may grow to a large size and is native to east and Southeast Asia (Watters, 1997). The rapid dispersal of this species has recently been recognized, with reports of its occurrence in Serbia (Paunovic et al., 2006), Poland (Kraszewski, 2007), the Czech Republic (Vrtílek and Reichard, 2012), and Romania (Popa et al., 2007) in the Danube basin. The initial introduction and spread of A. woodiana is thought to have occurred via the export of fish species such as Carassius auratus, C. gibelio, Ctenopharyngodon idella, and Hypophthalmichthys molitrix from eastern Asia for ornamental or biological control purposes (Watters, 1997). Carassius species in particular have spread extensively in Turkish waters (Tarkan et al., 2012) and C. gibelio is known to occur in Lake Sapanca (A.S. Tarkan, unpublished data), and is also distributed throughout the country, raising the possibility that $A$. woodiana may be more widespread in the region than this

\section{References}

Allen DC, Vaughn, CC (2011). Density-dependent biodiversity effects on physical habitat modification by freshwater bivalves. Ecology 95: 1013-1019.

Akyurt İ, Erdoğan O (1993). A study on some biological traits and meat production of fresh water mussels (Unio sp.) collected from the Müceldi and Karasu streams. Atatürk Univ Agriculture Faculty J 24: 98-107.

Albay M, Akçaalan R. Tüfekçi, H, Metcalf, SJ, Beattie, AK, Codd, AG (2003). Depth profiles of cyanobacterial hepatotoxins (microcystins) in three Turkish freshwater lakes. Hydrobiologia 505: 89-95.

APHA, AWWA and WPCF (1985). Standard Methods for the Examination of Water and Wastewater, 16th Edition (Greenberg AE, Trussel RR, Clesceri LS, Franson MAH, editors). Washington, DC: American Public Health Association. single case might suggest. A recent study on the invasion success of $A$. woodiana demonstrated that it is a successful invasive species tolerant of a wide range of environmental conditions (Douda et al., 2012). Monitoring of freshwaters in the vicinity of Lake Sapanca and elsewhere in western Turkey is warranted to measure the potential spread of this species.

In conclusion, the present study provides baseline data for future work on some ecologically important and common freshwater bivalves, some of which have not been previously studied in this respect in Turkey. These data facilitate more effective conservation measures for native mussel species, which are under threat of pollution, habitat degradation, and nonnative species introductions. All of these threats were apparent in the present study of Lake Sapanca and it is likely that bivalve populations face similar challenges elsewhere in Turkey, as well as in other areas of the Black Sea region in which these mussels are native. Further comprehensive studies focusing particularly on the ecology and habitat requirements of native and nonnative mussel species are warranted to better understand the conservation status of native mussels, not only in the Lake Sapanca basin, but also elsewhere in Turkey.

\section{Acknowledgments}

We thank Matej Polačik, Meriç Albay, Latife Köker, and Adnan Sümer for their invaluable help in sampling and water quality analyses. This study was financially supported by CSF 13-05872S. We thank the Sapanca Inland Fish Aquaculture and Research Application Station of the Fisheries Faculty of İstanbul University and the Republic of Turkey Ministry of Food, Agriculture, and Livestock for facilities and permits necessary to conduct the study. In addition, we thank the 2 anonymous reviewers for their useful comments to improve the paper.

Baker SM, Hornbach DJ (2000). Physiological status and biochemical composition of a natural population of unionid mussels (Amblema plicata) infested by zebra mussels (Dreissena polymorpha). Am Midl Nat 143: 443-452.

Başçınar S (2003). Investigation population parameters of freshwater mussels and economic evaluation possibility in Lake Çıldır. CFRI Yunus Res Bull 3: 16-20.

Bauer G (1988). Threats to the freshwater pearl mussel Margaritifera margaritifera L. in central Europe. Biol Conserv 45: 239-253.

Bilgin FH (1980). Taxonomy and distribution of mollusc species collected from some important freshwater systems in western Anatolia. Dicle Med J 8: 1-64.

Cuttelod A, Seddon M, Neubert E (2011). European Red List of Non-marine Molluscs. Luxembourg: Publications Office of the European Union. 
Dillon RT (2000). The Ecology of Freshwater Mussels. Cambridge: Cambridge University Press.

Douda K (2010). Effects of nitrate nitrogen pollution on Central European unionid bivalves revealed by distributional data and acute toxicity testing. Aquatic Conserv Mar Freshw Ecosyst 20: 189-197.

Douda K, Vrtílek M, Slavík O, Reichard M (2012). The role of host specificity in explaining the invasion success of the freshwater mussel Anodonta woodiana in Europe. Biol Invasions 14: 127137.

DSI (2005). Hidroelektrik santrallerde sorun yaratan zebra midye araştırmaları. Ankara: DSI.

Ercan E (2009). Sazan balığı (Cyprinus carpio L.,) Yetiştiriciliğinde Atık Suların Biyolojik Entegre Sistemle Arıtımının Araştırılması Üzerine Bir Çalışma. PhD, İstanbul University, Institute of Sciences, İstanbul.

Francis RICC (1990). Back-calculation of fish length: a critical review. J Fish Biol 36: 883-902.

Gaygusuz Ö, Gürsoy Gaygusuz Ç, Tarkan AS, Acıpınar H, Türer Z (2007). Preference of zebra mussel, Dreisena polymorpha in the diet and effect on growth of gobiids: a comparative study between two different ecosystems. Ekoloji 17: 1-6.

Green RH (1980). Role of a unionid clam population in the calcium budget of a small Arctic lake. Can J Fish Aquat Sci 37: 219-224.

Howard JK, Cuffe KM (2006). The functional role of native freshwater mussels in the fluvial benthic environment. Freshwat Biol 51: $460-474$.

İlhan R, Gökoğlu M, Gülyavuz H (2004). The chemical composition and the flesh yield of river mussel (Unio crassus Philipsson, 1788). Turk J Aquat Life 2: 205-210.

Kara C (2004). Some biological properties of Unio pictorum (L., 1758) which lived in Gavur Lake (Kahramanmaraş). KSU J Eng Sci 7: 9-12.

Killeen ID, Aldridge C, Oliver G (2004). Freshwater Bivalves of Britain and Ireland. Shrewsbury, UK: FSC Publications.

Kiss A (1994). Growth and production of the three Unionid mussel species in the river Tisza at Szeged. Available online at http:// benko.mgk.u-szeged.hu/cikkek/UNIOSZEG.pdf, 04.01.2013.

Koşal Şahin S, Yıldırım Z (2007). The mollusk fauna of Lake Sapanca (Turkey: Marmara) and some physico-chemical parameters of their abundance. Turk J Zool 31: 47-52.

Köhler R (2006). Observations on impaired vitality of Unio crassus (Bivalvia: Najadae) populations in conjunction with elevated nitrate concentration in running waters. Acta Hydroch Hydrob 34: 346-348.

Kraszewski A (2007). The continuing expansion of Sinanodonta woodiana (Lea, 1834) (Bivalvia: Unionidae) in Poland and Europe. Folia Malac 15: 65-69.

Lewandowski K (1976). Unionidae as a substratum for Dreissena polymorpha Pall. Polskie Archwm Hydrobiol 23: 409-420.
Lydeard C, Cowie RH, Ponder WF, Bogan AE, Bouchet P, Clark SA, Cummings KW, Frest TJ, Gargominy O, Herbert DG, et al. (2004). The global decline of nonmarine mussels. BioScience 54: 321-330.

May GE, Gelembiuk GW, Panov VE, Orlova MI, Lee CE (2006). Molecular ecology of zebra mussel invasions. Mol Ecol 15: 1021-1031.

Metcalfe NB, Monaghan P (2003). Growth versus lifespan: perspectives from evolutionary ecology. Exp Gerontol 38: 935-940.

Negus CL (1966). A quantitative study of growth and production of unionid mussels in the River Thames at Reading. J Anim Ecol 35: 513-532.

Neves RJ, Moyer SN (1988). Evaluation of techniques for age determination of freshwater mussels (Unionidae). Am Malacol Bull 6: 179-188.

Öktener A (2004). A preliminary research on Mollusca species of some freshwaters of Sinop and Bafra. G U J Sci 17: 21-30.

Pauly D (1980). On the interrelationships between natural mortality, growth parameters, and mean environmental temperature in 175 fish stocks. J Cons Int Explor Mer 39: 175-192.

Paunovic M, Csanyi B, Simic V, Stojanovic BCP (2006). Distribution of Anodonta (Sinanodonta) woodiana (Rea, 1834) in inland waters of Serbia. Aquat Invas 1: 154-160.

Popa OP, Kelemen BS, Murariu D, Popa LO (2007). New records of Sinanodonta woodiana (Lea, 1834) (Mollusca: Bivalvia: Unionidae) from eastern Romania. Aquat Invas 2: 265-267.

Ricker WE (1975). Computation and interpretation of biological statistics of fish populations. B Fish Res Board Can 191: 1-382.

Ryther JH, Yentsch CS (1957). The estimation of phytoplankton production in the ocean from chlorophyll and light data. Limnol Oceanogr 2: 228-286.

Schloesser DW, Nalepa TF, Mackie GL (1996). Zebra mussel infestation of unionid bivalves (Unionidae) in North America. Integr Comp Biol 36: 300-310.

Singer EE, Gangloff MM (2011). Effects of a small dam on freshwater mussel growth in an Alabama (USA) stream. Freshwater Biol 56: 1904-1915.

Son MO (2007). Native range of the zebra mussel and quagga mussel and new data on their invasions within the Ponto-Caspian region. Aquat Invas 2: 174-184.

Strayer DL (2008). Freshwater Mussel Ecology: A Multifactor Approach to Distribution and Abundance. Berkeley, CA: University of California Press.

Tarkan AS, Copp GH, Top N, Özdemir N, Önsoy B, Bilge G, Filiz H, Yapıcı S, Ekmekçi G, Kırankaya Ş et al. (2012). Are introduced gibel carp Carassius gibelio in Turkey more invasive in artificial than in natural waters? Fisheries Manag Ecol 19: 178-187.

Vaughn CC, Nichols SJ, Spooner DE (2008). Community and foodweb ecology of freshwater mussels. J N Am Benthol Soc 27: 409-423. 
Vaughn CC (2010). Biodiversity losses and ecosystem function in freshwaters: emerging conclusions and research directions. BioScience 60: 25-35.

Vrtílek M, Reichard M (2012). An indirect effect of biological invasions: the effect of zebra mussel fouling on parasitisation of unionid mussels by bitterling fish. Hydrobiologia 696: 205-214.

Watters GT (1997). A synthesis and review of the expanding range of the Asian freshwater mussel Anodonta woodiana (Lea, 1834) (Bivalvia: Unionidae). Veliger 40: 152-156.

Yalçın M (2006). Effect of environmental factors on growth, biochemical parameters and condition index in freshwater mussel (Unio pictorum Linnaeus, 1758). MSc, Ondokuz Mayıs University, Institute of Sciences, Samsun.
Yllmaz Ö (2011). Examination of the heavy metal levels in water, sediment, and Unio crassus (Bivalvia: Unionidae) samples taken from Dipsiz-Çine Stream (Muğla, Aydın). MSc, Muğla University, Institute of Sciences and Technology, Muğla.

Zar JH (1999) Biostatistical Analysis, 4th edition. Upper Saddle River, NJ: Prentice Hall.

Zettler ML, Jueg U (2007). The situation of the freshwater mussel Unio crassus (Philipsoni 1788) in northeast Germany and its monitoring in terms of the EC Habitats Directive. Mollusca 25: 165-74. 